\title{
Effect of Hydraulic Retention Time (HRT) on Surveillance of Coliforms in Waste Stabilization Pond (WSP) System in Central India
}

\author{
Kapilesh Jadhav*, Indrani Jadhav and Bilore SK
}

School of Studies in Botany, Institute of Environment Management and Plant Sciences (IEMPS), Vikram University, Ujjain, India

\begin{abstract}
The content of total coliforms and fecal coliforms were measured for the different ponds (anaerobic, facultative

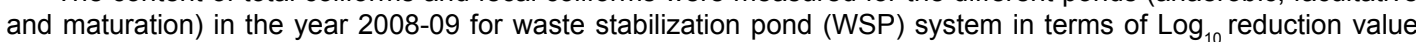
and decay rate $\left(k^{-1}\right)$ in order to determine the efficacy of waste stabilization ponds with respect to their hydraulic retention time (HRT). Physical and chemical parameters (temperature, hydrogen ion concentration, total suspended solids and total dissolved solids) were also determined with aim of finding the factors which influence the rate of coliforms removal. The results indicate the surveillance of coliforms were most favored in anaerobic cell and lest favored in maturation cell with decay rate to an average of $\left(k d^{-1}=2.92\right) ;\left(k d^{-1}=4.88\right) ;\left(k d^{-1}=5.83\right)$ and $\left(k d^{-1}=2.80\right)$ and $\left(k d^{-1}=4.30\right)$; $\left(k d^{-1}=5.89\right)$ for total coliforms and fecal coliforms observed for anaerobic, facultative and maturation cells respectively. The highest removal of coliforms (total and fecal coliforms) between $3.37 \log _{10}$ to $4.0 \log _{10}$ was observed for maturation cells with hydraulic retention time (HRT) of 5 days each and two maturation ponds in series.
\end{abstract}

Keywords: HRT; Fecal coliforms; Total coliforms; Waste stabilization pond system; Decay rate $\left(k d^{-1}\right)$

\section{Introduction}

Natural wastewater treatment systems have been widely used over the last few years as an alternative to conventional systems for the sanitation of small communities due to their minimum electric requirements and low maintenance costs [1-5]. Nowadays, WSPs are often regarded as the 'method of choice' for many wastewater treatment applications around the world; something owing to their more costeffective, flexible and sometimes more efficient operation [6-8], for this reasons WSPs have been used as promising wastewater treatment alternatives to the more expensive conventional systems, especially in developing countries [9-10]. WSP is not a new technology in India. The Central Public Health Engineering Research Institute had organized a symposium on WSP over 40 years ago [11] and published a WSP guidance manual [12].

Hydrology in part determines the functioning of wetlands, and this relation is particularly important in wetland designed and construction of wastewater treatment [13-15]. A longer stay of water in surface-flow treatment wetlands may enhance removal capacity of pollutants by longer contact time with surface and higher sedimentation rate at lower current velocities [16-17]. Previous research indicates that enteric microbe removal efficiency in wetlands can be affected by changes in hydraulic loading rate (HLR) and resultant hydraulic retention time (HRT) [18], the presence of vegetation [19], and whether the systems are surface flow (SF) or subsurface flow (SSF).

Considering Indian scenario not much research is done on WSP system, though India has most favorable condition for its functioning. Here in this study we have examined the efficiency of one of the major WSP system located in holy city of Ujjain in central India, in terms of coliforms (total and fecal indicator) removal with respect to its HRT.

\section{Study site}

The experimental pond systems were located at the sewage farm, which is $2 \mathrm{~km}$ away from city. The wastewater mainly comes from Rudrasagar, Barnagar, Charkrateerth and Somwariya through different pipelines system into pretreatment unit. The cardinal points are $23^{\circ} 13^{\prime}$ North latitude and $75^{\circ} 50^{\prime}$ East longitude, Altitude of the city is $510 \mathrm{~m}(1688 \mathrm{ft})$ above mean sea level. The peculiar topography of this area is wild plants with flat valley separated with topography height. The main stream Kshipra river flowing along the city from Southeast to Northwest direction. Average annual rainfall of Ujjain city is approximately $1100 \mathrm{~mm}$ though this has decrease drastically in the recent year to drought like condition (source : Ujjain development plans, Town country learning department M.P.) Temperature and metrological observation indicates that the mean and the maximum temperature range between $25^{\circ} \mathrm{C}$ and $45^{\circ} \mathrm{C}$. The overall unit comprises eight different cells; 2-Anaerobic, 2-Facultative and 4- Maturation Ponds. Total in flow of water in the cells is $52.7 \mathrm{~m}^{3}$ day $^{-1}$ (Figure 1), with retention time of 1day in Anaerobic Pond, 5 days in Facultative Ponds and 5 days in Maturation Ponds. Table 1 shows the total surface area of WSP system is 2,99,995 $\mathrm{m}^{2}$ with EFF/total depth of $4 \mathrm{~m} / 4.50 \mathrm{~m}$ for anaerobic cell and $1.5 \mathrm{~m} / 2.5 \mathrm{~m}$ for facultative cell and $1.5 \mathrm{~m} / 2.66 \mathrm{~m}$ for maturation cell. The study was performed in the year 2008 to 2009 for three seasons viz; winter, summer and post-monsoon.

\section{Methods and Materials}

\section{Sampling and analysis}

Wastewater samples were taken from inlet and outlet of each cell at the mean depth of $25 \mathrm{~cm}$ from the surface at $0.1100 \mathrm{~h}$ which gave the values equivalent to the mean effluent concentrations over $24 \mathrm{~h}$ period [20]. Column sample were used to measure the meant effluent quality [21]. Physicochemical parameters such as temperature, $\mathrm{pH}$, conductivity, turbidity, and total dissolved solids were measured in situ

${ }^{*}$ Corresponding author: Kapilesh Jadhav, School of Studies in Botany, Institute of Environment Management and Plant Sciences (IEMPS), Vikram University, Ujjain, India, E-mail: jadhavkapilesh@gmail.com

Received April 25, 2013; Accepted July 16, 2013; Published July 23, 2013

Citation: Jadhav K, Jadhav I, Bilore SK (2013) Effect of Hydraulic Retention Time (HRT) on Surveillance of Coliforms in Waste Stabilization Pond (WSP) System in Central India. Hydrol Current Res 4: 154. doi:10.4172/2157-7587.1000154

Copyright: ( 2013 Jadhav K, et al. This is an open-access article distributed unde the terms of the Creative Commons Attribution License, which permits unrestricted use, distribution, and reproduction in any medium, provided the original author and source are credited. 


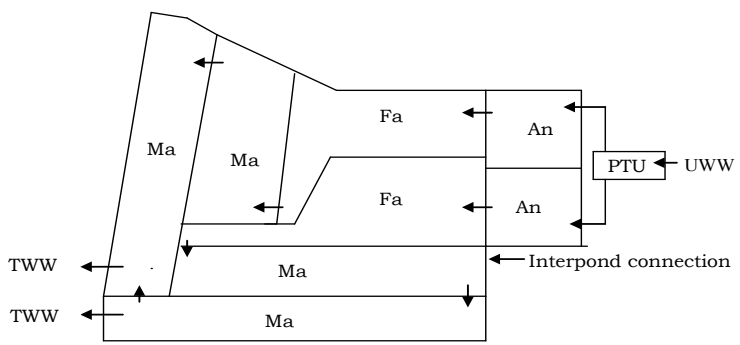

An- Anaerobic Pond, Fa- Facultative Pond, Ma- Maturation Pond ,UWW- Untreated water, TWW- Treated water

Figure 1: Schematic layout of WSP system. There are eight different cells in the wsp: 2-Anaerobic, 2-Facultative and 4- Maturation Ponds. Total in flow of water in the cells is $52.7 \mathrm{~m}^{-3}$ day $^{-1}$ with retention time of 1 day in Anaerobic Pond, 5 days in Facultative Ponds and 5 day in Maturation Ponds. The flow of water is diagonally from one cell to another.

\begin{tabular}{|c|c|c|c|}
\hline S.No. & Name of Unit & Surface area $\left(\mathrm{m}^{2}\right)$ & Total depth \\
\hline 1 & Anaerobic Pond (A1) & 6595 & 4.50 \\
\hline 2 & Facultative Pond (F1) & 87423 & 2.50 \\
\hline 3 & Maturation Pond (M1) & 103664 & 2.66 \\
\hline 4 & Maturation Pond (M2) & 102313 & 2.66 \\
\hline & Total & $2,99,995$ & \\
\hline
\end{tabular}

Table 1: Total depth and surface area of different ponds of WSP.

as describe in Standard Methods [22]. For data analysis the SPSS 17 statistical program was used.

\section{Total coliforms and fecal coliforms enumeration and estimation}

A series of fermentation tube containing sterile MacConkey bile salt lactose broth was distributed in $10 \mathrm{ml}$ amounts into tubes containing an inverted Durham vials and sterilized. The dilution series of water samples used in the case were $10^{-6}, 10^{-8}, 10^{-10} .10 \mathrm{ml}, 1 \mathrm{ml}, 0.1 \mathrm{ml}$ sample were used to inoculate double and single strength medium. A set of five replica tubes for each dilution were inoculated and incubated at $37^{\circ} \mathrm{C}$ for $24 \mathrm{hrs}$. Coli aerogenes group of organisms will ferment lactose to give acid and gas. The production of acid is shown by a change in colour of the yellow and gas was seen in Durham's tube. There must be sufficient gas to fill the concavity at the end of the Durham's tube before a positive result was to be recorded. Any sample which were negative, were re-incubated for a further $24 \mathrm{hrs}$ [23]. Confirmative test was carried out by using brilliant green lactose bile broth, 3 loopful of growth from each tube showing positive presumptive test were transferred to the Brilliant Green Lactose Bile (BGLB) broth tubes. These tubes were incubated at $35 \pm 2^{\circ} \mathrm{C}$. Those tubes which showed production of gas in the basal part of inverted Durham tube after 24 hrs were recorded. Ten milliliter of the medium was added to each tube containing an inverted Durham's tube and sterilized at $15 \mathrm{lbs}$ pressure for 15 minutes. Combinations of positive and negative tubes were compared with figure in MPN index table and probable number of total coliforms was determined. The completed test was applied to the brilliant green lactose bile broth fermentation tubes showing gas in the confirmative test. Eosine Methylene Blue (EMB) agar plates were streaked with a loopful inoculum from each tube of positive BGLB broth tubes. The plates were incubated at $37^{\circ} \pm 2^{\circ} \mathrm{C}$ for $24 \mathrm{hrs}$. The colonies developed on EMB medium plate were observed for typical and for atypical or negative colonies. Typical colonies were with or without metallic sheen, mucoid and pink while all other were negative colonies representatives. Typical colonies were transferred to nutrient agar slant for further differentiation of coliforms bacteria. This test was applied to different coliforms of fecal origin from coliforms of other sources. Three loopful of growth from all positive presumptive tubes from the total coliforms MPN test i.e. MacConkey bile salt lactose peptone water were inoculated in E.C. medium and incubated in water bath at 44.5 $\pm 0.2^{\circ} \mathrm{C}$ for $24 \mathrm{hrs}$. Gas production in the fermentation tubes within $24 \pm 2 \mathrm{hr}$ were considered as positive reaction indicating presence of coliforms, which were fecal in origin. Fecal coliforms densities were calculated by comparing the combination of positive and negative tubes with MPN index table.

\section{Decay $\left(\mathbf{k ~ d}^{-1}\right)$ of coliforms group}

The reductions of coliforms group of bacteria were enumerated by Most Probable Number (MPN) analysis and results were calculated as $\mathrm{CFU} / 100 \mathrm{ml}$ of the sample. The reduction of the coliforms in different cells was expressed as overall decay rate $\left(\mathrm{k} \mathrm{d}^{-1}\right)$ and is derived from the first order equation:

The decrease in the concentration of coliforms over time can be written as:

$$
\text { - } \mathrm{d}[\mathrm{A}] / \mathrm{dt}=\mathrm{k}[\mathrm{A}] \ldots \ldots \ldots \ldots \ldots . . . \mathrm{eq}-1
$$

Rearrangement of eq-1 and integrating the equation yields:

$$
\begin{aligned}
& \ln [A]=-k t+\ln [A]_{o} \ldots \ldots \ldots \ldots . . . e q-2 \\
& \ln \left([A] /[A]_{o}\right)=-k t \ldots \ldots \ldots \ldots . . . e q-3
\end{aligned}
$$

Where $\mathrm{A}$ and $\mathrm{A}$ is the concentration of the microorganisms (fecal and total coliforms) from inlet and outlet of each cell, $t$ is the time in days and $\mathrm{k}$ is the decay rate $\left(\mathrm{d}^{-1}\right)$.

\section{Results}

The summary of the main variables both influent and final effluent concentration and their average percentage removal in the WSP system is presented in Table 2 . The geometric mean concentrations of total coliforms and fecal coliforms was found significantly higher in influent $\left(2.87 \mathrm{E}+10\right.$ and $1.02 \mathrm{E}+10$ colony forming units (CFU) $100 \mathrm{~mL}^{-1}$ respectively) then in final effluent and were significantly reduced in each cell of the WSP system (Tables 3 and 4). The statical variance (viz; low, median and maximum values) for total and fecal coliforms (Figures 2 and 3) for different seasons were found to be lies between an average value of 3.31 to 10.01 with median of 5.7 for total coliforms and 2.54 to 8.82 with median of 4.96 for fecal coliforms. The $\log _{10}$ reduction for coliforms (total and fecal coliforms) was observed to be $6.70 \log _{10}$ and $6.28 \log _{10}$ values (Table 7) for whole WSP system with HRT of 15 days. On performing regression analysis $\left(\mathrm{R}^{2}\right)$ for $\log _{10}$ values as a function of HRT, results in a significant value of 0.99 and 1 , which show a positive correlation between reduction of coliforms and HRT (Figure 4). The

\begin{tabular}{|c|c|c|c|c|}
\hline Variables & Units & Influent Effluent\% removal & & \\
\hline $\mathrm{BOD}$ & $\mathrm{mg} / \mathrm{l}$ & 140.23 & 38.32 & 72.67 \\
\hline $\mathrm{COD}$ & $\mathrm{mg} / \mathrm{l}$ & 159.55 & 41.93 & 73.71 \\
\hline $\mathrm{DO}$ & $\mathrm{mg} / \mathrm{l}$ & 0.00 & 7.41 & ---- \\
\hline $\mathrm{TKN}$ & $\mathrm{mg} / \mathrm{l}$ & 13.42 & 11.50 & 14.3 \\
\hline $\mathrm{NO}_{3} \mathrm{~N}$ & $\mathrm{mg} / \mathrm{l}$ & 2.71 & 1.32 & 51 \\
\hline $\mathrm{NH}_{4} \mathrm{~N}$ & $\mathrm{mg} / \mathrm{l}$ & 7.55 & 2.87 & 61.8 \\
\hline $\mathrm{TS}$ & $\mathrm{mg} / \mathrm{l}$ & 1.37 & 1.04 & 22.08 \\
\hline
\end{tabular}

BOD; Biological Oxygen Demand, COD; Chemical Oxygen Demand, DO; Dissolved Oxygen, TKN; Total Kjeldahl Nitrogen, NO3N; Nitrate Nitrogen, NH4 N Ammonium Nitrogen,TS; Total Solid

Table 2: Average influent and effluent concentrations of the main variables and coliforms for integrated WSP system. 
Citation: Jadhav K, Jadhav I, Bilore SK (2013) Effect of Hydraulic Retention Time (HRT) on Surveillance of Coliforms in Waste Stabilization Pond (WSP) System in Central India. Hydrol Current Res 4: 154. doi:10.4172/2157-7587.1000154

Page 3 of 5

average decay rate (Table 5 and 6) was found to increase with increase in HRT and was observed highest for maturation cells and lowest for anaerobic cell, this indicates that surveillance of indicator bacteria is highest in anaerobic cell with HRT of 1 day and lowest in maturation cells with HRT of 5 days each.

\section{Discussion}

Different processes may be involved in the removal of microorganisms in a natural wastewater treatment system. It is worth mentioning that apart from other variables (light intensity, temperature, $\mathrm{pH}$ etc.) the hydraulic retention time (HRT) is an important parameter in removal of indicator bacteria. In this study, we evaluated the removal efficiency of coliforms by integrated WSP system located in central India. The WSP system removes the coliforms (total and fecal) with an efficiency of $>90 \%$ (Table 3 and 4 ) which are par with the range previously reported for WSPs for treatment of domestic

\begin{tabular}{|c|c|c|c|c|}
\hline Pond & Month & Influent & Effluent & $\%$ removal \\
\hline Anaerobic & Winter & $1.20 \mathrm{E}+10$ & $5.30 \mathrm{E}+08$ & 96 \\
\hline & Summer & $1.30 \mathrm{E}+10$ & $6.40 \mathrm{E}+08$ & 95 \\
\hline & Post manson & $6.32 \mathrm{E}+10$ & $4.50 \mathrm{E}+05$ & 93 \\
\hline Facultative & Winter & $5.67 \mathrm{E}+06$ & $3.01 \mathrm{E}+05$ & 95 \\
\hline & Summer & $6.14 \mathrm{E}+06$ & $2.34 \mathrm{E}+05$ & 96 \\
\hline & Post manson & $4.60 \mathrm{E}+04$ & $1.23 \mathrm{E}+03$ & 97 \\
\hline Maturation & Winter & $7.50 \mathrm{E}+04$ & $8.90 \mathrm{E}+02$ & 99 \\
\hline & Summer & $5.60 \mathrm{E}+04$ & $9.00 \mathrm{E}+02$ & 98 \\
\hline & Post manson & $6.70 \mathrm{E}+04$ & $1.10 \mathrm{E}+03$ & 98 \\
\hline
\end{tabular}

Table 3: Concentration in CFU/100ml and percentage removal for total coliforms in different cells of WSP as enumerated for different seasons in year 2008-09.

\begin{tabular}{|c|c|c|c|c|}
\hline Pond & Month & Influent & Effluent & $\%$ removal \\
\hline Anaerobic & Winter & $9.00 \mathrm{E}+09$ & $5.80 \mathrm{E}+08$ & 94 \\
\hline & Summer & $1.00 \mathrm{E}+10$ & $6.10 \mathrm{E}+08$ & 94 \\
\hline & Post manson & $1.05 \mathrm{E}+10$ & $5.90 \mathrm{E}+08$ & 94 \\
\hline Facultative & Winter & $7.32 \mathrm{E}+06$ & $6.10 \mathrm{E}+05$ & 92 \\
\hline & Summer & $6.47 \mathrm{E}+06$ & $3.54 \mathrm{E}+05$ & 95 \\
\hline & Post manson & $4.64 \mathrm{E}+06$ & $3.14 \mathrm{E}+05$ & 93 \\
\hline Maturation & Winter & $5.60 \mathrm{E}+04$ & $1.03 \mathrm{E}+03$ & 98 \\
\hline & Summer & $6.50 \mathrm{E}+04$ & $7.50 \mathrm{E}+02$ & 99 \\
\hline & Post manson & $6.60 \mathrm{E}+04$ & $8.20 \mathrm{E}+02$ & 99 \\
\hline
\end{tabular}

Table 4: Concentration in CFU/100ml and percentage removal for fecal coliforms in different cells of WSP estimated for different seasons in year 2008-09.

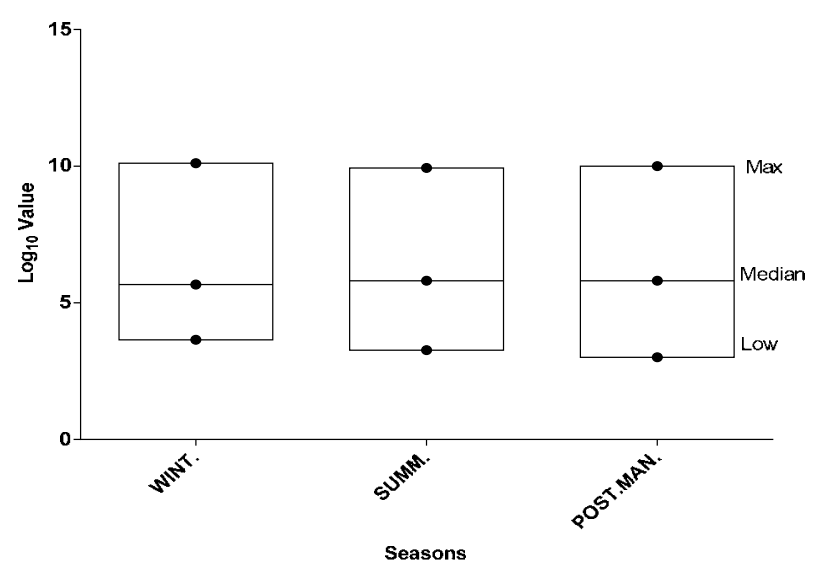

Figure 2: Statistical variance (low, median and max of Log10 value) of total coliforms for different seasons (viz; winter, summer and post monsoon) in the year 2008-2009. wastewater [24-25]. The low surveillance of coliforms in facultative and maturation cells seems to be due adsorption onto settleable solids, further sedimentation [26] and solar irradiation [27-28] are thought to be the main bacterial removal mechanisms in this cells, with lower depth, although other factors as predation by antagonistic organisms [29], physicochemical conditions [30-31] and toxins excreted by certain algae [32] could also affect the removal of microorganisms. Variability in concentration of coliforms were observed in the WSP system, may be due to seasonal and climatic conditions as seen in data observed for different seasons, as well as differences in the prevalence of infection and fecal excretion levels.

\section{Conclusions}

In conclusions, the assessment of coliforms (fecal and total) concentration in different cells of WSP, revels that the effectiveness of removal of indicator bacteria lies in condition prevailed in different

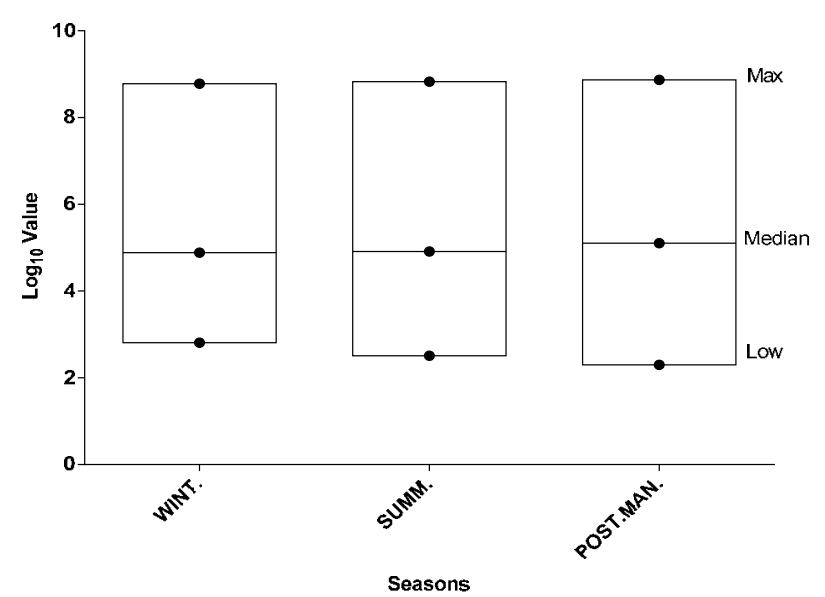

Figure 3: Statistical variance (low, median and max of Log10 value) of fecal coliforms for different seasons (viz; winter, summer and post monsoon) in the year 2008-09.
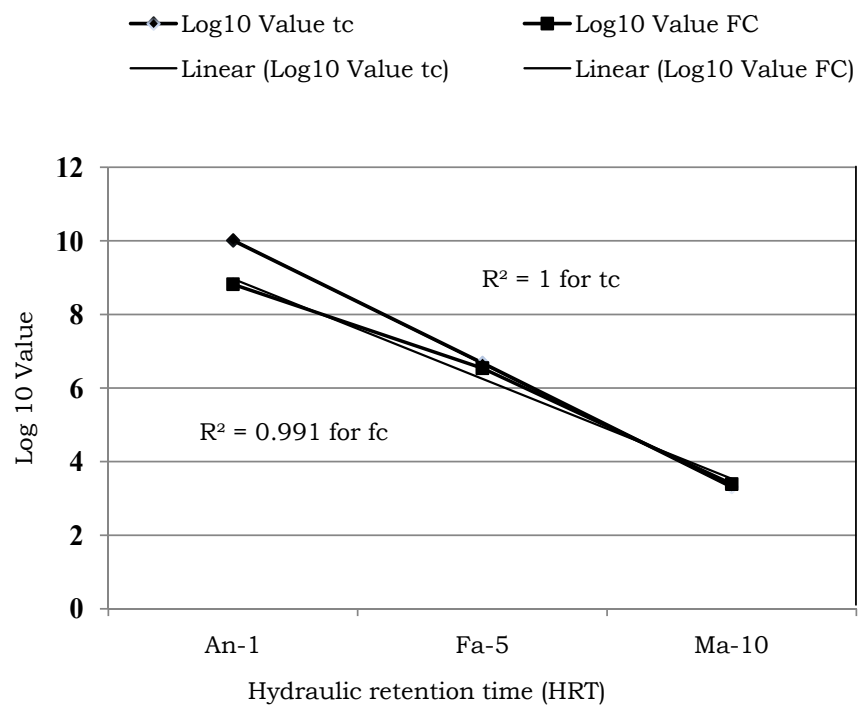

Figure 4: The average $\log _{10}$ reduction of total and fecal coliforms as a function of hydraulic retention time for different ponds (anaerobic, Facultative and maturation).An-1; Anaerobic pond with HRT of 1 day, Fa-5; Facultative pond with HRT of 5 days, Ma-10; Maturation pond with HRT of 10 days. 
Citation: Jadhav K, Jadhav I, Bilore SK (2013) Effect of Hydraulic Retention Time (HRT) on Surveillance of Coliforms in Waste Stabilization Pond (WSP) System in Central India. Hydrol Current Res 4: 154. doi:10.4172/2157-7587.1000154

\begin{tabular}{|c|c|c|}
\hline Cell & Season & Decay rate $\left[k\left(d^{-1}\right)\right]$ \\
\hline Anaerobic & Winter & 3.11 \\
\hline & Summer & 3.01 \\
\hline & Post manson & 2.64 \\
\hline Facultative & Winter & 4.54 \\
\hline & Summer & 4.87 \\
\hline & Post manson & 5.23 \\
\hline Maturation & Winter & 6.04 \\
\hline & Summer & 5.74 \\
\hline & Post manson & 5.71 \\
\hline
\end{tabular}

Table 5: Decay rate $\left[k\left(d^{-1}\right)\right]$ of total coliforms in different ponds of WSP calculated from first-order equation $d A / d t=-k C$.

\begin{tabular}{|c|c|c|}
\hline Cell & Season & Decay rate $\left[k\left(d^{-1}\right)\right]$ \\
\hline Anaerobic & Winter & 2.74 \\
\hline & Summer & 2.80 \\
\hline & Post manson & 2.88 \\
\hline Facultative & Winter & 4.09 \\
\hline & Summer & 4.52 \\
\hline Maturation & Post manson & 4.30 \\
\hline & Winter & 5.61 \\
\hline & Summer & 6.07 \\
\hline & Post manson & 6.00 \\
\hline
\end{tabular}

Table 6: Decay rate $\left[k\left(d^{-1}\right)\right]$ of fecal coliforms in different cells of WSP calculated from first-order equation $d A / d t=-k C$.

\begin{tabular}{|c|c|c|c|c|c|c|c|c|c|c|}
\hline \multicolumn{3}{|c|}{ Indicator/Seasons } & \multicolumn{4}{c|}{ total coliforms } & \multicolumn{5}{c|}{ fecal coliforms } \\
\hline $\begin{array}{c}\text { Ponds } \\
\text { Ponds }\end{array}$ & $\mathrm{A}$ & $\mathrm{F}$ & $\mathrm{M} 1$ & $\mathrm{M} 2$ & $\begin{array}{l}\mathrm{log}_{10} \\
\text { Red }\end{array}$ & $\mathrm{A} 1$ & $\mathrm{~F} 1$ & $\mathrm{M} 1$ & $\mathrm{M} 2$ & $\begin{array}{l}\mathrm{log}_{10} \\
\text { Red }\end{array}$ \\
\hline Winter & 10.11 & 6.6 & 4.74 & 3.65 & 6.46 & 8.78 & 6.50 & 3.27 & 2.81 & 5.97 \\
\hline Summer & 9.94 & 6.77 & 4.85 & 3.27 & 6.67 & 8.83 & 6.53 & 3.30 & 2.51 & 6.32 \\
\hline $\begin{array}{c}\text { Post } \\
\text { monsoon }\end{array}$ & 10.0 & 6.69 & 4.93 & 3.01 & 6.99 & 8.87 & 6.61 & 3.3 .6 & 2.30 & 6.57 \\
\hline $\begin{array}{c}\text { Average } \\
\text { Value }\end{array}$ & 10.01 & 6.68 & 4.84 & 3.31 & 6.70 & 8.82 & 6.54 & 3.39 & 2.54 & 6.28 \\
\hline
\end{tabular}

A; Anaerobic pond; Facultative pond, M1; Maturation pond 1, M2; Maturation pond 2

Table 7: $\log _{10}$ values for total and fecal coliforms calculated for three different seasons (winter, summer and Post monsoon) in year 2008-09.

pond of the system. The maturation ponds play a vital removal of coliforms due to high DO content, rise in hydrogen concentration and large surface area which are responsible for low surveillance rate. The study also suggests that pond with large surface (in this study) and two maturation ponds in series can result in better quality of effluent.

\section{Acknowledgement}

The authors extend their gratitude towards Public Health Department (PHE) and Ujjain development plans, town country learning department M.P. of Ujjain for their technical assistance during sampling procedure and providing relevant literature of WSP system.

\section{References}

1. Mara DD, Mills SW, Pearson HW, Alabaster GP (1992) Waste stabilization ponds: A viable alternative for small community treatment systems. JIWEM 6: 72-78.

2. Brix H (1994) Constructed wetlands for municipal wastewater treatment in Europe. Elsevier.

3. Vymazal J (2002) The use of sub-surface constructed wetlands for wastewater treatment in the Czech Republic: 10 years experience. Ecol Eng 18:633-646.

4. Bécares $E$ (2006) Limnology of natural systems for wastewater treatment. Ten years of experiences at the experimental field for low-cost sanitation in Mansilla de las Mulas (León, Spain). Limnética 25:143-154.
5. Puigagut J, Villaseñor J, Salas JJ, Bécares E, García J (2007) Subsurfaceflow constructed wetlands in Spain for the sanitation of small communities: a comparative study. Ecol Eng 30: 312-319.

6. Cauchie HM, Hoffmann L, Thomé JP (2000a) Metazooplankton dynamics and secondary production of Daphnia magna (Crustacea) in an aerated waste stabilization pond. Journal of Plankton Research 22: 2263-2287.

7. Mara D (2001) Development of a new approach to waste stabilization pond design: TPHE Research Monograph No. 5, School of Civil Engineering University of Leeds, Leeds, England.

8. Mara DD (2004) Natural sewage treatment in the UK: selection guidelines. Water and Environment Journal 18: 230-234.

9. Kivaisi AK (2001) The potential for constructed wetlands for wastewater treatment and reuse in developing countries: a review. Ecol Eng 16: 545-560.

10. Song M, Chu S, Letcher RJ, Seth R (2006) Fate, partitioning, and mass loading of polybrominated diphenyl ethers (PBDEs) during the treatment processing of municipal sewage. Environ Sci Technol 40: 6241-6246.

11. Central Public Health Engineering Research Institute (CPHERI) (1963) Proceedings of Symposium on Public Health Engineering Education, Nagpur India.

12. Arceivala SJ, Lakshminarayana JSS, Alagarsamy SR, Sastry CA (1970) Waste Stabilization Ponds: Design,Construction and Operation in India. Nagpur: Central Public Health Engineering Research Institute.

13. Gossleink JG, RE Turner (1978) The role of hydrology in freshwater wetland ecosystem: Fresh water wetlands: Ecological processes and management potential, Academic press, New York.

14. Carter V, Bedinger MS, Novitzki RP, Wilen WO (1979) Water resources and wetlands: Wetland functions and values: The state of our understanding American Water Resources Association, 649.

15. Howaed-Williama C (1985) Cycling and retention of nitrogen and phosphorous in wetlands: a theoretical and applied prespective. Fresh water Biology 15: 391 431

16. Reddy KR, De Busk TA (1987) State-of-the-art utilization of aquatic plants in water pollution control. Water Science and Technology 10: 61-79.

17. Kadlec RH and Knight RL (1996) Costructed Wetlands, Boca Raton, Florida Lewis Publisher.

18. Tanner CC, Clayton JS, Upsdell MP (1995) Effect of loading rate and planting on treatment of dairy farm wastewaters in constructed wetlands; Removal of oxygen demand, suspended solids and fecal coliforms. Water Research 29 : $17-26$

19. Soto F, Garcia M, Luis E and Bécares E (1999) Role of Scirpus lacustris in bacterial and nutrient removal from wastewater. Water Science and Technology 40: $241-47$.

20. Silva SA (1982) On the Treatment of Domestic Sewage in Waste Stabilization Ponds in Northeast Brazil: PhD Thesis, University of Dundee, Dundee Scotland, Department of Civil Engineering, 203.

21. Pearson HW, Mara DD, Arridge HA (1995) The influence of pond geometry and configuration on facultative and maturation waste stabilization pond performance and efficiency. Water Science and Technology 31: 129-139.

22. American Public Health Association/American Water Works Association/Water Environment Federation (1999) Standard Methods for the Examination of Water and Wastewater. (20 $0^{\text {th }}$ edn), Washington, DC, USA, 50.

23. Dart RK and Stretton RJ (1980) Microbiological Aspects of Pollution Control. Amsterdam, New York, Elsevier Scientific Publication.

24. Greenway M (2005) The role of constructed wetlands in secondary effluent treatment and water reuse in subtropical and arid Australia. Ecol Eng 25: 501 509

25. Morsy EA, Al-Herrawy AZ, Ali MA (2007) Assessment of Cryptosporidium removal from domestic wastewater via constructed wetland systems. Water Air Soil Pollut 179: 207-15.

26. Grimason AM, Wiandt S, Baleux B, Thitai WN, Bontoux J, et al. (1996) Occurrence and removal of Giardia sp. cysts by Kenyan and French waste stabilisation pond systems. Water Sci Technol 33: 83-89.

27. Curtis TP, Mara DD, Silva SA (1992) The effect of sunlight on faecal coliforms 
Citation: Jadhav K, Jadhav I, Bilore SK (2013) Effect of Hydraulic Retention Time (HRT) on Surveillance of Coliforms in Waste Stabilization Pond (WSP) System in Central India. Hydrol Current Res 4: 154. doi:10.4172/2157-7587.1000154

Page 5 of 5

in ponds. Implications for research and design. Water Sci \& Technol 26:17291738.

28. Davies-Colley RJ, Donnison AM, Speed DJ (1997) Sunlight wavelengths inactivating faecal indicator microorganisms in waste stabilisation ponds. Water Sci Technol 35: 219-225

29. Manage PM, KawabataZ, NakanoS, Nishibe $Y$ (2002) Effect of heterotrophic nanoflagellates on the loss of virus-like particles in pond water. Ecol Res 17: 473-479.

30. Araki S, González JM, De Luis E, Bécares E (2000) Viability of nematode eggs in HRAP. Effect of the physico-chemical conditions. Water Sci Technol 42: 371 374

31. Araki S, Martín-Gomez S, Bécares E, De Luis-Calabuig E, Rojo-Vazquez F (2001) Effect of high-rate algal ponds on viability of Cryptosporidium parvum oocysts. Appl Environ Microbiol 67: 3322-3324.

32. Oufdou K, Mezrioui N, Oudra B, Loudiki M, Barakate M, et al. (2001) Bioactive compounds from Pseudanabaena species (Cyanobacteria). Microbios 106 Suppl 1: 21-29. 